INFINITY-Jurnal Matematika dan Aplikasinya (IJMA)

Volume 1 | Nomor 2 | Maret | 2021

\title{
Algoritma Chaid Pada Klasifikasi Rumah Tangga Miskin Kota Palopo
}

\section{Yuli Hastuti' ${ }^{1}$, Muhammad Muzaini²}

\author{
Corespondensi Author \\ IInstitut Agama Islam Negeri Ambon, \\ Ambon Indonesia \\ 2Universitas Cokroaminoto Palopo, \\ Fakultas Sains, Palopo, Indonesia
}

[ [Email: yulihastuti@iainambon.ac.id] 2[Email:muhammadmuzaini@uncp.ac.id]
Abstrak. Penelitian ini bertujun untuk mengklasifikasikan status rumah tangga miskin Kota Palopo yaitu menggunakan metode CHAID. Variabel (dependen) adalah status kemiskinan sedangkan variabel bebasnya meliputi status kepala rumah tangga, pendapatan per bulan, status pekerjaan, pendidikan terakhir kepala rumah tangga, luas lantai rumah, jenis atap rumah, jenis lantai rumah, jenis dinding rumah, status kepemilikan rumah, sumber penerangan rumah, sumber air untuk minum, tempat buang air besar, dan tempat buang sampah. Hasil analisis CHAID menunjukkan bahwa dari 13 variabel yang telah diolah hanya ada 3 variabel yang berasosiasi atau memiliki keterkaitan dengan status kemiskinan yaitu pendapatan per bulan, jenis lantai rumah, dan status pekerjaan. Variabel pendapatan per bulan sebagai child awal atau kedalaman dengan p-value 0,0001, variabel jenis lantai rumah sebagai child kedua atau kedalaman dengan p-value 0,0151, dan variabel status pekerjaan sebagai child ketiga atau kedalaman diperoleh dengan $\mathrm{p}$-value 0,0001 , artinya variabel pendapatan per bulan, jenis lantai rumah dan status pekerjaan memiliki keterkaitan terhadap status kemiskinan karena nilai $p$-value lebih kecil dari nilai $\alpha=0,05$. Model CHAID yang diperoleh menggambarkan bahwa rumah tangga di Kelurahan Pontap dan Ponjalae Kecamatan Wara Timur berstatus miskin jika kepala rumah tangga yang berpendapatan < 500.000 ada yang memiliki lantai rumah keramik, atau lantai rumah semen, sedangkan untuk kategori kepala rumah tangga yang berpendapatan $>500.000$ ada yang status pekerjaan berusaha sendiri dan status pekerjaan buruh tidak tetap. Tingkat ketepatan model CHAID dalam mengklasifikasikan rumah tangga miskin di Kelurahan Pontap dan Ponjalae Kecamatan Wara Timur sebesar $98,5 \%$. 


\section{PENDAHULUAN}

Kemiskinan merupakan salah satu permasalahan bagi negara berkembang, pengentasan kemiskinan dan menciptakan kesejahteraan bagi rakyat merupakan tujuan akhir suatu negara, dalam koteks ini Indonesia sebagai negara berkembang yang masih dihinggapi oleh masalah kemiskinan, 14\% rakyat Indonesia dari kurang lebih 240 juta jiwa saat ini masih dikategorikan sebagai rakyat miskin dengan menggunakan indikator berpendapatan $1 \$$ per hari, artinya masih ada sekitar 30 juta rakyat miskin di Indonesia. Yang lebih ironis apabila kita menggunakan indikator dari bank dunia, rakyat miskin adalah orang yang berpendapatan kurang dari $2 \$$ per hari, maka angka tersebut melonjak menjadi 35\% (Pratama, 2014). Kondisi kemiskinan suatu negara atau daerah juga merupakan cerminan dari tingkat kesejahteraan penduduk yang tinggal pada negara/daerah tersebut (Teddy, 2013). Indonesia adalah negara yang tergolong masih berkembang dan kemiskinan merupakan masalah yang masih menjadi perhatian.

Menurut Badan Pusat Statistik (BPS), kesejahteraan merupakan repersentase yang bersifat kompleks karena mempunyai keterkaitan multidimensi. Secara umum kesejahteraan dapat diukur dari sisi demografi, kecukupan pangan, pendidikan, kesehatan, ketenagakerjaan, dan kondisi lingkungan. Kemiskinan merupakan bentuk untuk meraih kesejahteraan dipandang dari sisi ekonomi dalam memenuhi kebutuhan dasar makanan dan bukan makanan yang diukur dari sisi pengeluaran. BPS mencatat jumlah penduduk miskin Indonesia pada bulan September 2016 (penduduk dengan pengeluaran per kapita per bulan dibawah garis kemiskinan) di Indonesia mencapai 27,76 juta orang $(10,70 \%)$, berkurang sebesar 0,25 juta orang dibandingkan dengan kondisi Maret 2016 yang sebesar 28,01 juta orang $(10,86 \%)$. Persentase penduduk miskin di daerah perkotaan pada Maret 2016 sebesar 7,79\%, turun menjadi 7,73\% pada September 2016. Demikian pula persentase penduduk miskin di daerah pedesaan turun dari 14,11\% pada Maret 2016 menjadi 13,96\% pada September 2016. Meski selama periode Maret 2016-September 2016 persentase kemiskinan menurun, namun jumlah penduduk miskin di daerah perkotaan naik sebanyak 0,15 juta orang (dari 10,34 juta orang pada Maret 2016 menjadi 10,49 juta orang pada September 2016), sementara di daerah pedesaan turun sebanyak 0,39 juta orang (dari 17,67 juta orang pada Maret 2016 menjadi 17,28 juta orang pada September 2016) (BPS, 2016).

Salah satu metode dalam tehnik klasifikasi yaitu metode CHAID (Chi-Squared Automatic Interaction Detector). Metode CHAID merupakan metode yang relatif baru. Metode ini pertama kali diperkenalkan oleh Dr. G. V. Kass pada tahun 1980 pada sebuah artikel berjudul "An Exploratory Techmique for Investigation Large Quantities of Categorial Data" dalam buku Applied Statistics. Metode CHAID umumnya dikenal sebagai metode pohon klasifikasi (Classification Tree Method). Inti dari metode ini adalah membagi data menjadi kelompok-kelompok yang lebih kecil berdasarkan keterkaitan antara variabel dependen dengan variabel independen. Analisis CHAID digunakan ketika data yang dipakai adalah data dengan variabel-variabel kategorik. Variabel kategorik yaitu variabel yang memberikan label sesuai pengamatan dan dialokasikan untuk salah satu dari beberapa kemungkinan kategori, misalnya golongan darah $0, A, B$, dan $A B$ (Everit \& Skrondal, 2010).

Berdasarkan uraian latar belakang, dapat dirumuskan masalah yang akan diteliti yaitu bagaimana cara mengklasifikasikan kasus rumah tangga miskin di Kota Palopo menggunakan metode algoritma CHAID. Berdasarkan rumusan masalah, maka tujuan penelitan ini yaitu membentuk metode algoritma CHAID dan menentukan cara mengklasifikasikan rumah tangga miskin di Kota Palopo menggunakan Algoritma CHAID. 


\section{METODE}

Data penelitian ini berupa data primer yaitu hasil survei yang dilakukan penelitian tentang data kemiskinan Kota Palopo tahun 2018. Tabel berikut memuat rincian tentang variabel yang digunakan dalam penelitian di Kelurahan Pontap dan Ponjalae Wara Timur Kota Palopo tahun 2018. Sampel diambil secara acak dari Kelurahan Pontap dan Ponjalae Kecamatan Wara Timur Kota Palopo jumlah data yang diperoleh sebanyak 65 rumah tangga yang terdiri dari 40 rumah tangga di Kelurahan Pontap dan 25 rumah tangga di Ponjalae Kecamatan Wara Kota Palopo (Lihat Tabel 1).

Tabel 1. Variabel penelitian

\begin{tabular}{llc}
\hline & \multicolumn{1}{c}{ Variabel Dependen } & $\begin{array}{c}\text { Skala } \\
\text { Data }\end{array}$ \\
\hline $\mathrm{Y}$ & Status kemiskinan & Nominal \\
\hline \multicolumn{3}{c}{ Variabel Independen } \\
\hline $\mathrm{X}_{1}$ & Status kepala rumah tangga & Nominal \\
$\mathrm{X}_{2}$ & Pendapatan kepala rumah tangga & Ordinal \\
$\mathrm{X}_{3}$ & Status pekerjaan & Nominal \\
$\mathrm{X}_{4}$ & Pendidikan terakhir kepala rumah & Ordinal \\
& tangga & \\
$\mathrm{X}_{5}$ & Luas lantai rumah & Ordinal \\
$\mathrm{X}_{6}$ & Jenis lantai rumah & Nominal \\
$\mathrm{X}_{7}$ & Jenis atap rumah & Nominal \\
$\mathrm{X}_{8}$ & Jenis dinding rumah & Nominal \\
$\mathrm{X}_{9}$ & Status kepemilikan rumah & Nominal \\
$\mathrm{X}_{10}$ & Sumber penerangan rumah & Nominal \\
$\mathrm{X}_{11}$ & Sumber air untuk minum & Nominal \\
$\mathrm{X}_{12}$ & Tempat buang air besar & Nominal \\
$\mathrm{X}_{13}$ & Tempat buang sampah & Nominal \\
\hline
\end{tabular}

Tahapan umum penelitian ini yaitu pengumpulan data, pengolahan dan penyajian data, proses analisis data, interpretasi dan penentuan kesimpulan. Teknik analisis data yang dilakukan untuk mencapai tujuan penelitian yang telah disebutkan terdiri dari proses pembentukan metode CHAID dengan data rumah tangga miskin di Kota Palopo dan proses penerapan metode tersebut dalam memprediksi data dalam rumah tangga miskin Kota Palopo.

Algoritma CHAID dengan data rumah tangga miskin di Kota Palopo dibentuk untuk memprediksi karekterisasi data rumah tangga miskin di Kota Palopo. Berikut ini algoritma CHAID langkah-langkah sebagai berikut (Pratama, 2011).

1. Tahap penggabungan:

a. Menentukan nilai significant level untuk penggabungan $\left(\alpha_{\text {merger }}\right)$ dan significant level untuk pembagian $\left(\alpha_{\text {split }}\right)$, dimana $\alpha_{\text {merger }}<\alpha_{\text {split }}$.

b. Melakukan uji hipotesis dari setiap pasangan kategori pada masing-masing prediktor, untuk melihat apakah kategori-kategori tersebut memberikan perbedaan yang signifikan terhadap variabel target. Tingkat signifikansi ini dilihat dari $p$-value yang diperoleh dari hasil pengujian.

c. Membandingkan $p$-value terbesar dari pasangan kategori-kategori pada suatu variabel prediktor dengan $\alpha_{\text {merger }}$ yang telah ditentukan sebelumnya. 
1. Jika $p$-value lebih besar dari $\alpha_{\text {merger }}$ maka gabungkan pasangan ini menjadi suatu susunan tunggal. Dengan demikian akan terbentuk suatu susunan kategori baru dari variabel target, lalu kemudian mengulangi proses dari awal.

2. Jika $p$-value lebih kecil dari $\alpha_{\text {merger }}$, maka lanjut ke langkah selanjutnya.

d. Menghitung $p$-value penyesuaian dari kategori-kategori prediktor dan variabel target dengan menggunakan bonferroni adjustment yang sesuai.

2. Tahap pembagian (splitting), memilih prediktor yang memiliki $p$-value penyesuaian terkecil, yang menunjukkan variabel yang paling signifikan. Bandingkan $p$-value ini dengan $\alpha_{\text {split }}$ :

a. Jika $p$-value lebih kecil atau sama dengan $\alpha_{\text {split }}$, maka bagi node ini berdasarkan kategori-kategori prediktor pada node tersebut.

b. Jika $p$-value lebih besar dari $\alpha_{\text {split }}$, maka node ini merupakan node terakhir.

Tahap penghentian (stopping), melanjutkan proses pertumbuhan pohon sampai menemui aturan untuk berhenti, yaitu ketika tidak ada variabel independen yang menunjukkan $p$-value yang signifikan.

\section{HASIL DAN PEMBAHASAN}

Data hasil survei 65 rumah tangga di Kota Palopo yang dilakukan di Kelurahan Pontap dan Ponjalae Kecamatan Wara Timur digunakan untuk mengetahui karakteristik status kemiskinan rumah tangga tersebut menggunakan metode CHAID. Karakter rumah tangga yang diperhatikan adalah status pekerjaan, pendidikan terakhir kepala rumah tangga, status kepala rumah tangga, luas lantai rumah, jenis lantai rumah, jenis dinding rumah, jenis atap rumah, sumber air untuk minum, tempat buang air besar, tempat buang sampah dan pendapatan. Diagram pohon CHAID pada klasifikasi rumah tangga miskin Kelurahan Pontap dan Ponjalae Kecamatan Wara Timur Kota Palopo. Berikut ini tahap analisis metode algoritma CHAID.

\section{A. Penggabungan kategori}

Proses penggabungan dilakukan dengan menggabungkan antar kategori (intrance) masing-masing variabel independen yang memiliki kategori lebih dari dua dimana penggabungan kategori dilakukan apabila hasil uji independensi antar kategori bernilai signifikan. Variabel yang memiliki lebih dari dua kategori pada penelitian ini adalah status pekerjaan, pendidikan terakhir kepala rumah tangga, jenis lantai rumah, jenis atap rumah, jenis dinding rumah, status kepemilikan rumah, sumber penerangan rumah, sumber air untuk minum, tempat buang air besar dan tempat buang sampah. Hasil penggabungan menunjukkan bahwa hanya variabel status pekerjaan dan jenis lantai rumah yang signifikan pada penggabungan kategori.

Kategori status pekerjaan diberikan coding kategori 0 untuk status pekerjaan buruh tidak tetap, kategori 1 untuk status pekerjaan berusaha sendiri, kategori 2 untuk status pekerjaan lainnya, dan kategori 3 untuk status pekerjaan PNS. Berdasarkan hasil deskripsi pada tabel 5 diketahui bahwa tidak ada responden yang berstatus PNS. Pekerjaan dari kategori lainnya adalah buruh tetap. Hasil pengujian statistik chi-square pada kombinasi penggabungan yang sudah dilakukan dapat dilihat dalam tabel 15 .

Nilai $p$-value $>\alpha=0,05$ untuk hasil uji independensi gabungan kombinasi status pekerjaan buruh tidak tetap (0) dan status pekerjaan berusaha sendiri (1) serta gabungan kombinasi status pekerjaan buruh tidak tetap (0) dan status pekerjaan lainnya (2). Hal ini menunjukkan bahwa kategori status pekerjaan buruh tidak tetap (0) 
saling bebas dengan kategori yang lain. Oleh Karena itu, kategori status pekerjaan buruh tidak tetap (0) tidak digabungkan dengan katgeori yang lain. Nilai $p$-value $<\alpha=0,05$ untuk hasil uji independensi gabungan kombinasi status pekerjaan berusaha sendiri (1) dan status pekerjaan lainnya (2). Pengali bonferroni untuk variabel independen status pekerjaan dihitung berdasarkan persamaan (2), diperoleh nilai pengali bonferroni sebesar 7, maka nilai uji signifikan dengan koreksi bonferroni sebesar $(0,0001)(7)=$ 0,0007 . Nilai $p$-value terkoreksi lebih kecil dari nilai $\alpha=5 \%$, artinya status pekerjaan berusaha sendiri (1) dan status pekerjaan lainnya digabungkan untuk proses CHAID selanjutnya.

\begin{tabular}{ccccc} 
Tabel 2. Hasil uji chi-square proses penggabungan kategori status pekerjaan \\
\hline $\begin{array}{c}\text { Kategori } \\
\text { status }\end{array}$ & $\begin{array}{c}\text { Kategori } \\
\text { status }\end{array}$ & $\begin{array}{c}\text { Nilai } \\
\boldsymbol{x}^{2} \text { hitung }\end{array}$ & p-value & Keterangan \\
kemiskinan & pekerjaan & & & \\
\hline 0 dan 1 & 0 dan 1 & 32,48 & 0,307 & Signifikan \\
0 dan 1 & 0 dan 2 & 27,0 & 0,71 & Signifikan \\
0 dan 1 & 1 dan 2 & 1,44 & 0,0001 & Tidak signifikan \\
\hline
\end{tabular}

\section{B. Tahap Pembagian (Spiltting)}

Tahap splitting digunakan untuk menentukan node yang berasosiasi dengan varaibel dependen. Variabel yang berasosiasi langsung dengan variabel dependen disebut node awal. Variabel independen yang signifikan tidak saling bebas dengan variabel dependen dan memiliki nilai hitung uji chi-square terbesar menjadi node awal. Iterasi splitting selanjutnya mengulangi proses tersebut berdasarkan node parent, dan seterusnya.

Hasil uji chi-square pada tabel 2 menunjukkan bahwa variabel independen yang signifikan tidak saling bebas dengan status kemiskinan adalah varaibel pendapata per bulan, status pekerjaan, luas lantai rumah, status kepemilikan rumah, dan tempat buang air besar. Kesimpulan tersebut berdasarkan nilai $p$-value $<\alpha=0,05$. Variabel independen yang signifikan tersebut, variabel status pekerjaan memiliki nilai chi-square hitung sebesar 34,692 sehingga status pekerjaan sebagai node awal. Artinya, status pekerjaan berasosiasi langsung dengan status kemiskinan rumah tangga di kelurahan tersebut.

Tabel 3. Hasil uji chi-square penentuan node awal

\begin{tabular}{lcccl}
\hline \multicolumn{1}{c}{ Kategori variabel inpenden } & $\begin{array}{c}\text { Kategori } \\
\text { variabel } \\
\text { independen }\end{array}$ & $\begin{array}{c}\text { Nilai } \\
\boldsymbol{x}^{2} \text { hitung }\end{array}$ & $\begin{array}{c}p \text { - } \\
\text { value }\end{array}$ & Keterangan \\
\hline Status kepala rumah tangga & 0 dan 1 & 0,718 & 0,397 & $\begin{array}{l}\text { tidak } \\
\text { signifikan }\end{array}$ \\
Pendapatan per bulan & 0 dan 1 & 13,878 & 0,0001 & signifikan \\
$\begin{array}{l}\text { Status pekerjaan } \\
\text { Pendidikan terakhir kepala rumah }\end{array}$ & 0 dan $(1,2)$ & 34,692 & 0,0001 & signifikan \\
tangga & $1,2,3,4$ & 0,613 & 0,893 & $\begin{array}{l}\text { Tidak } \\
\text { signifikan }\end{array}$ \\
$\begin{array}{l}\text { Luas lantai rumah } \\
\text { Jenis lantai rumah }\end{array}$ & 0 dan 1 & 5,679 & 0,017 & $\begin{array}{l}\text { Signifikan } \\
\text { tidak }\end{array}$ \\
Jenis dinding rumah & 0 dan $(1,2)$ & 3,367 & 0,067 & $\begin{array}{l}\text { signifikan } \\
\text { tidak } \\
\text { signifikan }\end{array}$
\end{tabular}


Status kepemilikan rumah

Sumber penerangan rumah

Sumber air minum

Tempat buang air besar

Tempat buang sampah

\begin{tabular}{|c|c|c|c|}
\hline $0,1,2$ & 1,772 & 0,018 & Signifikan \\
\hline $0,1,2,3$ & 2,308 & 0,315 & tidak \\
\hline $0,1,2,3$ & 1,772 & 0,832 & $\begin{array}{l}\text { tidak } \\
\text { signifikan }\end{array}$ \\
\hline $0,1,2$ & 7,386 & 0,025 & Signifikan \\
\hline $0,1,2,3$ & 5,197 & 0,518 & $\begin{array}{l}\text { tidak } \\
\text { signifika }\end{array}$ \\
\hline
\end{tabular}

Iterasi kedua mengulangi proses splitting berdasarkan variabel status pekerjaan. Berdasarkan nilai $p$-value $>\alpha=0,05$ pada hasil uji chi-square menunjukkan bahwa tidak terdapat variabel independen yang signifikan berasosiasi dengan kategori status pekerjaan tidak tetap sehingga tidak ada node yang menjadi child dari kategori buruh tidak tetap. Variabel independen yang menjadi child untuk kategori gabungan status pekerjaan adalah variabel pendapatan per bulan karena memiliki nilai chi-square hitung paling besar yaitu sebesar 28,486 dibandingkan variabel lain yang juga signifikan. Artinya, status pendapatan per bulan berasosiasi dengan kategori gabungan status pekerjaan berusaha sendiri dan lainnya (buruh tetap).

Iterasi kedua mengulangi proses splitting berdasarkan variabel status pekerjaan. Berdasarkan nilai $p$-value $>\alpha=0,05$ pada hasil uji chi-square menunjukkan bahwa tidak terdapat variabel independen yang signifikan berasosiasi dengan kategori pendapatan $>$ 500.000 sehingga tidak ada node yang menjadi child dari kategori pendapatan $>500.000$. Variabel independen yang menjadi child untuk kategori pendapatan $<500.000$ adalah variabel jenis lantai rumah karena memiliki nilai chi-square hitung paling besar yaitu sebesar 7,879 dibandingkan variabel lain yang juga signifikan. Artinya, status jenis lantai rumah berasosiasi dengan kategori pendapatan $<500.000$.

\section{Tahap Penghentian (Stopping)}

Proses pembentukan pohon klasifikasi CHAID rumah tangga miskin berhenti pada kedalan ketiga dengan node terakhir adalah variabel jenis lantai rumah tidak ada variabel independen yang menunjukkan $p$-value yang signifikan berasosiasi dengan jenis lantai rumah berdasarkan status kemiskinan. Adapun diagram pohon klasifikasi CHAID rumah tangga miskin responden dapat dilihat dalam gambar 5 .

Diagram pohon CHAID pada gambar 1 menunjukkan bahwa dari 13 variabel yang telah diolah dengan $C H A I D$ hanya ada 3 variabel yang berasosiasi atau memiliki keterkaitan dengan status kemiskinan yaitu status pekerjaan, pendapatan per bulan dan jenis lantai rumah. Variabel status pekerjaan sebagai child awal atau kedalaman (depth) dengan $p$-value 0,0001, artinya status pekerjaan memiliki keterkaitan terhadap status kemiskinan karena nilai $p$-value lebih kecil dari nilai $\alpha=0,05$. Variabel pendapatan per bulan sebagai child kedua atau kedalaman (depth) dengan p-value 0,0001, artinya pendapatan per bulan memiliki keterkaitan terhadap status kemiskinan karena nilai $p$ value lebih kecil dari nilai $\alpha=0,05$. Variabel status jenis lantai rumah sebagai child ketiga atau kedalaman (depth) diperoleh dengan p-value 0,0151, artinya jenis lantai rumah memiliki keterkaitan terhadap status kemiskinan karena nilai $p$-value lebih kecil dari nilai $\alpha=0,05$. 


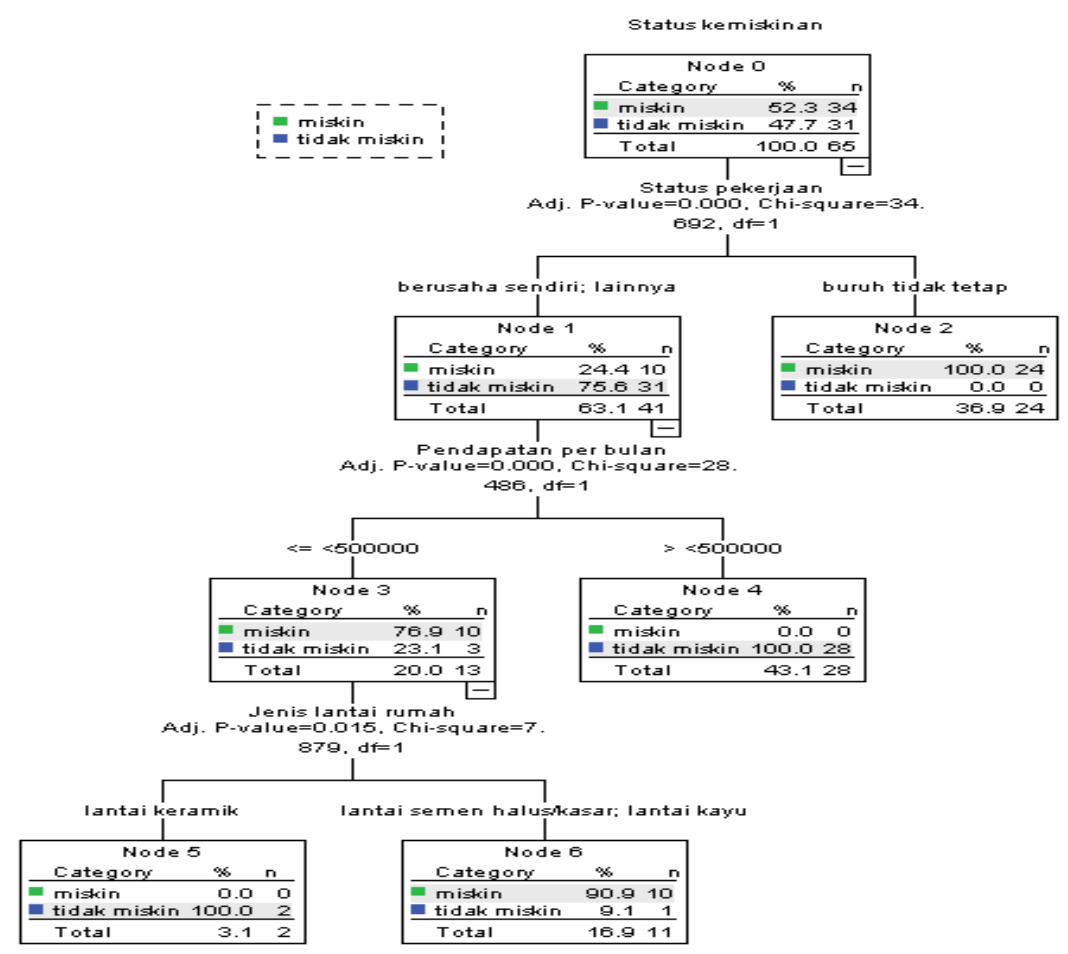

Gambar 1. Diagram CHAID rumah tangga miskin Kota Palopo

Berikut ini diberikan Tabel klasifikasi karakteristik rumah tangga miskin Kelurahan Pontap dan Ponjalae Kecamatan Wara Timur Kota Palopo berdasarkan diagram pohon pada Gambar 1.

Tabel 4. Pengklasifikasian rumah tangga miskin berdasarkan diagram pohon CHAID

\begin{tabular}{ccl}
\hline Klasifikasi & Node & \multicolumn{1}{c}{ Karakteristik } \\
\hline Rule 1 & $1,3,5$ & $\begin{array}{l}\text { Rumah tangga yang status pekerjaan } \\
\text { berusaha sendiri ada yang memiliki } \\
\text { pendapatan per bulan <500.000 dan jenis } \\
\text { lantai rumah keramik }\end{array}$ \\
Rule 2 & $1,3,6$ & $\begin{array}{l}\text { Rumah tangga yang status pekerjaan } \\
\text { berusaha sendiri ada yang memiliki } \\
\text { pendapatan per bulan <500.000 dan jenis } \\
\text { lantai rumah semen } \\
\text { Rumah tangga yang status pekerjaan }\end{array}$ \\
Rule 4 & 1,4 & $\begin{array}{l}\text { berusaha sendiri ada yang memiliki } \\
\text { pendapatan per bulan }>500.000 \\
\text { Rumah tangga yang status pekerjaan buruh } \\
\text { tidak tetap }\end{array}$ \\
\hline
\end{tabular}

Berdasarkan pengklasifikasian pada Tabel 4 maka berikut ini Tabel persentase masing-masing karakteristik (Lihat Tabel 5). 
Tabel 5. Persentase rumah tangga miskin berdasarkan karakteristik

\begin{tabular}{ccc}
\hline & \multicolumn{2}{c}{ Persentase karakteristik } \\
\cline { 2 - 3 } Klasifikasi & Miskin & Tidak miskin \\
\hline Rule 1 & $0,0 \%$ & $100,0 \%$ \\
Rule 2 & $90,9 \%$ & $9,1 \%$ \\
Rule 3 & $0,0 \%$ & $100,0 \%$ \\
Rule 4 & $100,0 \%$ & $0,0 \%$ \\
\hline
\end{tabular}

Tabel 5 memberikan informasi bahwa rumah tangga miskin persentase tertinggi pada segmentasi ke-2 yaitu sebanyak 100,0\% rumah tangga yang status pekerjaan buruh tidak tetap. Rumah tangga tidak miskin pada segmentasi ke-2 sebanyak 90,9\% merupakan rumah tangga yang status pekerjaan berusaha sendiri ada yang memiliki pendapatan per bulan $<500.000$ dan jenis lantai rumah semen.

Persentase pengklasifikasian rumah tangga miskin diatas memuat informasi tingkat risiko kesalahan metode CHAID dalam mengkasifikasikan data rumah tangga miskin responden. Tabel risk (Lihat Tabel 6) digunakan untuk menguji kebaikan model estimasi metode CHAID pada Gambar 1.

Tabel 6. Nilai risk metode CHAID

\begin{tabular}{cc}
\hline \multicolumn{2}{c}{ Risk } \\
\hline Estimate & Standar error \\
0,15 & 0,15 \\
\hline
\end{tabular}

Tabel 6 menunjukkan nilai estimasi risk sebesar 0,15\%. Hal ini memiliki arti bahwa model akan salah memprediksi atau salah mengklasifikasikan rumah tangga miskin sebesar 1,5\%.

Tabel 7. Persentase hasil klasifikasi rumah tangga miskin menggunakan metode CHAID

\begin{tabular}{cccc}
\hline \multirow{2}{*}{ Hasil survey } & \multicolumn{3}{c}{ Prediksi CHAID } \\
\cline { 2 - 4 } Miskin & Miskin & Tidak miskin & ketepatan prediksi \\
\cline { 2 - 4 } Tidak miskin & 34 & 0 & $100,0 \%$ \\
\hline Total & 1 & 30 & $96,8 \%$ \\
\hline
\end{tabular}

Tabel 7 menunjukkan bahwa metode CHAID mempredikisi rumah tangga miskin sebanyk 34 dan memprediksi rumah tangga tidak miskin sebanyak 30 dan memprediksi 1 rumah tangga tidak miskin sebagai rumah tangga miskin. Secara keseluruhan ketepatan klasifikasi rumah tangga miskin dengan metode CHAID adalah 98,5\%.

\section{KESIMPULAN}

Adapun kesimpulan yang diperoleh dari hasil penelitian algoritma CHAID pada klasifikasi rumah tangga miskin Kota Palopo Kelurahan Pontap dan Ponjalae Kecamatan Wara Timur didasarkan pada diagram pohon CHAID sebagai berikut:

1. Rumah tangga yang status pekerjaan berusaha sendiri ada yang memiliki pendapatan per bulan $<500.000$ dan jenis lantai rumah keramik 
2. Rumah tangga yang status pekerjaan berusaha sendiri ada yang memiliki pendapatan per bulan $<500.000$ dan jenis lantai rumah semen

3. Rumah tangga yang status pekerjaan berusaha sendiri ada yang memiliki pendapatan per bulan $>500.000$

4. Rumah tangga yang status pekerjaan buruh tidak tetap

Pada klasifikasi rumah tangga miskin Kelurahan Pontap dan Ponjalae Kecamatan

Wara Timur Kota Palopo tahun 2018, akurasi metode CHAID dalam mengklasifikasikan status kemiskinan sebesar 98,5\%.

Rekomendasi sebagai bahan pertimbangan dalam pengembangan metode CHAID penelitian status kemiskinan selanjutnya bisa menggunakan status kemiskinan lebih dari dua kategori seperti rumah tangga tidak miskin, miskin dan rumah tangga kurang (miskin). Selain itu, metode CHAID dapat dikembangkan menggunakan metode klasifikasi yang dapat menggunakan variabel independen skala campuran.

\section{REFERENSI}

Badan Pusat Statistik. 2016. Profil Kemiskinan di Indonesia. Indonesia.

Everit, B. S. dan A. Skrondal. 2010. The Cambridge Dictionary of Statistics Fourth Edition. Cambridge: Cambridge University Press.

Pratama, Edi. 2011. Analisis Faktor-faktor yang Memengaruhi Keputusan Pasien Rawat Jalan dalam Memilih Rumah Sakit dengan Menggunakan Algoritma CHAID. Universitas Indonesia. Depok.

Pratama, Y. C. 2014. Analisis Faktor-faktor yang Memengaruhi Kemiskinan di Indonesia. UIN Syarif Hidayatullah Jakarta.

Teddy, Christianto. 2013. Determinan dan Karakteristik Kemiskinan di Provinsi Riau. Volume VII, No. 2, Desember 2013 ISSN: 1978-3612. 